SABINA SOSIN

Uniwersytet Jagielloński w Krakowie

e-mail: sabinasosin@gmail.com

\title{
Formal Repetition as a Device Reinforcing the Theme of Powerlessness
}

\begin{abstract}
Innovative authors who explore various narrative techniques have often been inclined to tell one story from several different perspectives. The aim of this paper is to analyze formal repetition employed in three contemporary narratives: J.M. Coetzee's Diary of a Bad Year (2007), Dariusz Orszulewski's Jezus nigdy nie byt aż taki blady (2013), as well as House Mother Normal (1971) by these authors' avant-garde predecessor, B.S Johnson. Johnson was an author ahead of his time, better fitted in the literary discourse of the 21 st century, which is proven by his presently republished oeuvre having gained fresh literary significance among both scholars and readers. Each of the novels subject to analysis in this study is compiled from thoughts and observations of the same events but originating from different characters. Their individual accounts, typographically separated from each other, create a multitude of perspectives on the mental and physical inadequacy felt by the characters.
\end{abstract}

Keywords: multiple perspectives, formal repetition, B.S. Johnson, J.M. Coetzee, Dariusz Orszulewski.

\section{Introduction}

A multi-perspective narrative has been a favored device for contemporary authors who like to test the limits of literary expression. Not only does it challenge their creativity on the plot level but also offers an abundance of possibilities for formal experimentation aimed at finding perfect modes to fit particular literary content. This paper investigates the differences as well as common denominators between textual and material realizations of three post-modern repetitive narratives: B.S. Johnson's House Mother Normal (1971), Dariusz Orszulewski's Jezus nigdy nie byt aż taki blady (2013) and J.M. Coetzee's Diary of a Bad Year (2007). I argue that the material realization of these novels is an integral part of constructing the multiple perspectives and that all three can be regarded as examples of liberature - a literary category coined by Zenon Fajfer in 1999 who believes that 
"[t]he physical and spiritual aspects of the literary work, that is, the book and the text printed in it should complement each other to create a harmonious effect". By analyzing the form of repetition employed in each of them, I attempt to prove that, in these novels, the correlation between materiality and its textual content allows the authors to emphasize the theme of powerlessness which becomes a trait unifying these seemingly distinct works.

\section{B.S. Johnson's House Mother Normal}

The works of B.S. Johnson may have been first presented to the public in the 1960s and 70s but their rather quick sinking into oblivion indicates that the literary scene needed time to catch up with his uncompromised experimentations. It was only recently that interest in the author has been revived. ${ }^{2}$ With his works presently republished and gaining academic significance, B.S. Johnson may undoubtedly be labelled an author ahead of his time, better fitted in the $21^{\text {st }}$-century literary discourse. Johnson's oeuvre granted him the title of " "the one man avantgarde' of the 1960s"3 and has been an inspiration for many of the more innovative writers. He is also acknowledged by Fajfer as one of the most outstanding liberatic writers of the $20^{\text {th }}$ century. ${ }^{4}$

House Mother Normal, first published in 1971, is Johnson's fifth novel and is composed of nine successive chapters which provide a uniquely structured insight into the minds of eight nursing home inmates and their much younger caretaker, the House Mother. Each of these independent narratives is a separate take on the same events told from an individual perspective of just one of the characters. As these accounts are ordered from the most lucid to the most senile patient, together they create a poignant portrayal of dementia in progress.

The chapters are structurally identical - comprised of exactly twenty-one pages each, and marked with double pagination. Every chapter has its separate set of page numbers located in the top-right corner of the page. At the same time, there is another, traditionally-located pagination covering the entire text of the

1 Z. Fajfer, Liberature. Appendix to a Dictionary of Literary Terms [in]: Liberature or Total Literature, ed. and trans. K. Bazarnik, Kraków 2010, p. 25.

2 The second edition of House Mother Normal was published by New Directions in 1986, thirteen years after Johnson's death, and again became quickly forgotten. It was republished for the third time by Pan Macmillan in the 2004 Omnibus edition of Johnson's three novels, which followed the republication of his novel in a box, The Unfortunates, in 1999, and Jonathan Coe's biography, also issued in 2004. House Mother Normal was then published for the fourth time by Picador in 2012 and, very recently, by New Directions in 2016. Such a short period between two re-editions suggests that the novel has finally caught up with its readership.

J. Coe qtd. in J. Jordan, Introduction: Avant-Garde Possibilities - B.S. Johnson and the Sixties Generation [in:] B.S. Johnson and Post-War Literature: Possibilities of the Avant-Garde, eds. J. Jordan, M. Ryle, New York 2014, p. 1.

4 Johnson's works are mentioned as exemplary throughout all the 1999-2009 essays collected in Fajfer's manifesto Liberature or Total Literature (2010). Also, Polish translations of his novels have been a part of the Liberature series edited by Fajfer and Katarzyna Bazarnik and published by a Polish publishing house Korporacja Ha!Art. 
novel which suggests that, ultimately, House Mother Normal should be regarded as one entity and thus a representation of one degenerative process symbolized by the multiplication of gradually disintegrating voices. Nevertheless, the chapters remain visibly separated from one another with an imitation of "a clinical note" providing basic information about a given inmate and his or her health condition, further reflected in the account following the chart.

The structural framework of House Mother Normal plays an important role when paired with the parallel texts it contains. The medical charts clearly state that each consecutive inmate is less lucid than the former, but it is through the deterioration of their internal monologues that their mental deterioration is truly shown. Yet, this decline does not reveal itself in any descriptive scenes but in the typographical and linguistic fragmentation that increases with each chapter. The novel starts with an account by Sarah Lamson, a 74-year-old widow in a fairly good health condition. Her narration is coherent, marked with only sporadic gaps that do not impair the reader's understanding of the text and should rather be interpreted simply as Sarah's temporary absentmindedness. On the other side of the spectrum, there are two final chapters belonging to George Hedbury and Rosetta Stanton - two most senile patients whose accounts consist mostly of completely blank pages or ones with sparsely scattered individual words or letters. Retrieving any information from these sections is possible only through juxtaposing them with the rest of the novel. The middle part between these radically different stages of old age contains the chapters of the remaining five inmates which gradually lose their intelligibility. This degradation, which is clearly visible even while simply flipping through the pages of the novel, aptly captures the sad reality of the final stages of human life. Nicolas Tredell rightly points out that in the final chapters "the page of the novel is inverted; there is more white than black. In this respect, the pages are like tombstones, where blackness often outweighs the text". ${ }^{6}$ This notion is further reinforced by the final statement of all but Rosetta's accounts. "No, doesn't matter", ${ }^{7}$ conclude the inmates with resignation, which implies the futility of old age.

Interestingly, the only exception from the fixed order of the novel is the House Mother's account presented as the last one. She is the youngest of all Johnson's characters but, as Lars Bernaerts argues, such an ordering of chapters "suggests that [ethically] she is the most degenerate character of them all". ${ }^{8}$ Doubtless her controversial methods of caretaking keep the inmates' occupied and steer them away from depressive thoughts about their condition. Nonetheless, games such as passing around a box with her dog's excrements in it or a bestial act involving the

5 N. Tredell, Geriatric Comedy: House Mother Normal [in:] N. Tredell, Fighting Fictions: The Novels of B.S. Johnson, Nottingham 2010, p. 104.

6 Ibid., p. 106.

7 B.S. Johnson, House Mother Normal [in:] B.S. Johnson Omnibus, London 2004 (p. 5-204), p. 21. Further cited as HMN and a page number.

8 L. Bernaerts, Minds at Play. Narrative Games and Fictional Minds in B.S. Johnson's House Mother Normal, "Style" 2014, vol. 48, no. 3, p. 300. 
dog performed in front of them are downright offensive and present the inmates as helpless pawns in their caretaker's sick game.

When it comes to the methods of reading, there are two kinds of approach to House Mother Normal and the choice depends entirely on the reader. The novel may be read in a traditional, sequential manner, or by the parallel pages in the chapters since the individual pages mirror their respective contents as well. In the latter case, the overall context of the novel is being updated with every new chapter read and the reader must undertake a holistic reconstruction of the plot. The other method requires the reader to put together fragments related to only one aspect of the plot at a time. Yet, whatever choice the reader makes, the content of the novel remains unchanged. In both cases the reconstruction results in the same story of one evening told in nine distinctly different manners, which creates a tangible metaphor of senility turning people into shadows of their previous selves and leaving them at the mercy of others.

\section{Dariusz Orszulewski's Jezus nigdy nie był aż taki blady}

Quite recently, a novel written in a similar vein to Johnson's work was published in the same series of liberatic works created by Korporacja Ha!Art. Even though Dariusz Orszulewski's Jezus nigdy nie byt aż taki blady (2013) is a work clearly inspired by its avant-garde predecessor, it is even more liberal on the level of formal experimentation. Still, it operates on the same general principle. Upon initial investigation, the novel strikingly resembles House Mother Normal: it is divided into seven independent sections, the text of which keeps disintegrating to the point when it disappears completely. All sections have the same length of eleven pages, but their content is exactly the same in all seven cases, and there is no pagination whatsoever. Additionally, Orszulewski decided to make the print gradually fade out. Content-wise, this first-person narrative brings to mind a rather psychotic rant of a mentally unstable individual whose obsessive behavior is symbolized by the repetitiveness of the text. Although, initially, it seems to be a typical monologue, the text is filled with often-concealed but, nonetheless, direct replies and questions which suggest that the man has two mute or deliberately silenced interlocutors: his wife and his friend, Antosz. He keeps implying that Antosz is gone travelling ("Antosz, jak już się wreszcie zjawisz, to ja będę miał pare pytań"9), which may as well indicate that the parts of the monologue addressed to him are internalized. Yet, in other parts, he unmistakably responds to his wife's remarks ("Ja się czuję odrzucony? Ja się nie czuję odrzucony"10 JNNBATB., n. p.), which makes it quite clear that he is conversing with her, while her statements simply do not appear on the pages of the novel. The narrative is therefore much more complex than it appears at first sight.

9 "Antosz, when you finally come back, I will have some questions to ask" (my translation). Further cited as JNNBATB n. p. (as the book is not paginated).

10 "Do I feel rejected? No, I don't feel rejected?" (my translation). 
The repeated sections of Jezus are visibly separated from one another in a way resembling divisions used by Johnson in House Mother Normal. Here, the divider takes the form of a completely black page. This is, however, the last physical similarity between the novels as the multiplied text is not the only one embedded in Jezus. Each page is actually a half-folded, bigger sheet and conceals the second narrative printed on its inner part. To be able to read it, the reader has to cut the pages open with a knife. The hidden part of Jezus is a collection of several shorter texts which, contrary to the first monologue, are not repeated. It opens with a selfcritical confession, presumably made by the author of the monologue, and is followed by a few short comments from a woman who might be his wife. The final part is a considerably longer, coherent story that covers all the remaining inner pages of the novel and is written in a traditional third-person narration. Through a recount of a summer break which Hanna (the wife) decided to spend with her father in a resort where they used to go on holiday when she was little, it contemplates difficult family relationships, often caused by the inability or unwillingness to communicate, and the inevitable passage of time.

Bitterness and frustration prevail in the narratives of Jezus as its characters seem to be emotionally dysfunctional and distant from one another. They all seem to be related, yet there is no warmth and certainly no effective communication that should bind families together. The chaotic, diversified structure of the novel may indeed symbolize this inability to interact with others: a group of people, talking not to, but past each other, unable to communicate despite trying various means. This split is further reinforced by the reader with the knife in her hand who simultaneously provides more context and adds to the confusion as she, quite literally, tears the narrative apart.

Just as in the case of House Mother Normal, the reader can choose between two alternative readings: she may either finish the fading monologue first and then cut the pages open or cut them as she reads and let the narratives become interwoven. The other way, however, may result in an extremely confusing experience and render the story impossible to follow. Reading Jezus is thus very likely to be a one-time experience. After the book is finished, it does not seem probable that anyone will succeed or even attempt to reconstruct the story from the jumble it becomes after all the narratives are mixed together. The first reader turns the book into a hostile object against which the next person stands hopeless. This material transformation of the novel is an integral part of Orszulewski's experiment, which is a prominent feature of all works of liberature: the whole reading process drives the characters into even deeper despair and they cannot be helped since there is no way of putting their story back together. As a result, the novel's cut pages radiate the feeling of almost palpable inability. 


\section{J.M. Coetzee's Diary of a Bad Year}

Coetzee's novel neither takes repetition to a level as literal as the works discussed above, nor is the author an obvious name that comes to mind when liberature is discussed. Yet, his 2011 book fits this category quite well. It tells the story of a renowned, elderly writer who was asked to contribute his opinion to a book discussing various topics of modernity. Due to the progressing Parkinson's disease his hands are not steady anymore so he decides to hire his young, beautiful neighbor, Anya, to type the manuscript for him. The plot revolves around their relationship that is continuously threatened by Anya's jealous boyfriend, Alan, who feels intimidated by the writer and seeks revenge by stealing his money.

Although the novel focuses on one chain of events, typographically it is divided into three distinctive parts that appear on almost every page, separated from one another with a straight horizontal line. These sections vary in length, and constitute three different narratives. The first one is dedicated to the writer's manuscript in the form of short essays and is the outcome of the events taking place in the other two sections: one presenting the writer's perspective (J.C., which seems to be Coetzee's older alter-ego) and the other belonging to Anya. These two sections are practically inseparable - one without the other does not provide enough information for the reader to reconstruct the story. Their interconnectedness is also shown in the rising significance of Anya's contributions to J.C.'s opinions, when her "merely prosthetic function [of] transcribing [the writer's] words" shifts to the role of "a book editor" that "increasingly shapes [J.C's] worldview". ${ }^{11}$ But Anya's increasing authorial agency is caused not only by the growing fondness she and J.C. feel for each other, but mainly by the deteriorating physical condition of J.C. Without a typist, his opinions would most likely remain unheard. Nonetheless, the manuscript section presenting these opinions is not much discussed in the other sections. Only occasionally does Anya express her disapproval of some of J.C.'s opinions, and suggests he takes on a topic less detached from everyday life (he eventually does this in the second part of his opinions). As H. Abbott points out, "we experience the essays as interruptions of [the] narrative, self-contained and without, moreover, any particular temporal locations on the narrative time line". ${ }^{12}$ Whereas it is true that the essays do not contain any direct references to the other parts, they certainly help in their contextualization since while reading them, the reader familiarizes herself with Anya's editorial work and with J.C.'s sentiments. At the same time, this very first section which the reader becomes familiar with serves as a conclusion of the entire novel. Because of its presence, the reader immediately knows that the cooperation between the writer and his typist was brought to a successful closure and in spite of her boyfriend's mischievous plans, Anya was able to finish her work.

11 A. Hall, Disability and Life Writing in Coetzee's Later Works, "Journal of Literary \& Cultural Disability Studies” 2014, vol. 6, no. 1, p. 61.

12 H. Porter Abbott, Time, Narrative, Life, Death \& Text-Type Distinctions: The Example of Coetzee's Diary of a Bad Year, "Narrative" 2011, vol. 19, no. 2, p. 190. 
When it comes to J.C.'s and Anya's sections, they start at the same point and most of the time provide the reader with two different views on the same situations rather than simple descriptions of events. The reader is therefore presented with an already subjectified matter which she further processes. Just as in the case of House Mother Normal and Jezus, Diary of a Bad Year becomes a meaningful whole only after the reader becomes familiar with the entire novel, and the difficulty of the reconstruction very much depends on the method chosen by the reader to handle the sections. On the textual level exclusively, Coetzee's novel deals with processes responsible for shaping one's opinions. As Martin Puchner argues, "Coetzee turned the project of a novel of thinking into an explicit, thematic undertaking. The expression of ideas, the grounding of them in characters and finally the process by which they arrive at them, form a part of [the novel's] dramatic action". ${ }^{13}$ The action, however, continuously interacts with the material form of the novel and brings out its other motives. It is the typographical division into three sections which makes the reader realize the importance of Anya's work, her influence on J.C., and, as only one section belongs solely to him, the utterly helpless position in which the writer would find himself without his typist. Thus, in a very liberatic vein, the material form of Diary of a Bad Year is indispensable in revealing the novel's underlying themes related to disabilities caused by aging and the inability to be one's own man who does not have to depend on the help of others.

\section{Conclusions}

No matter how thematically different these three novels may at first appear, there are certain affinities between them which cannot be missed. Whether they center around an inability to communicate, to be self-sufficient or turn back the clock, they all are, ultimately, variations on the same motif: powerlessness. The structural repetitions employed in the novels are meant to emphasize this notion, but the multitude of perspectives presented in them invite the reader to consider more than one interpretation. Furthermore, the apparent impairment of the characters reinforces the readerly involvement in the formation of the story. The final conclusions are for her to make and depend on the amount of information she was able to restore.

13 M. Puchner, J.M. Coetzee's Novels of Thinking, "Raritan” 2011, vol. 30, no. 4, p. 6. 


\section{Bibliography}

Bernaerts L., Minds at Play. Narrative Games and Fictional Minds in B.S. Johnson's House Mother Normal, "Style” 2014, vol. 48, no. 3, p. 294-312.

Coetzee J.M., Diary of a Bad Year, London 2007.

Fajfer Z., Liberature or Total Literature, ed. and transl. K. Bazarnik, Kraków 2010.

Hall A., Disability and Life Writing in Coetzee's Later Works, "Journal of Literary \& Cultural Disability Studies” 2014, vol. 6, no. 1, p. 53-67.

Johnson B.S., House Mother Normal [in:] B.S. Johnson Omnibus, London 2004, p. 5-204.

Jordan J., B.S. Avant-Garde Possibilities - B.S. Johnson and the Sixties Generation [in:] Johnson and Post-War Literature: Possibilities of the Avant-Garde, eds. J. Jordan, M. Ryle, New York 2014, p. 1-13.

Orszulewski D., Jezus nigdy nie byt aż taki blady, Kraków 2013.

Porter Abbott H., Time, Narrative, Life, Death \& Text-Type Distinctions: The Example of Coetzee's Diary of a Bad Year, "Narrative" 2011, vol. 19, no. 2, p. 187-200.

Puchner M., J.M. Coetzee's Novels of Thinking, "Raritan" 2011, vol. 30, no. 4, p. $1-12$.

Tredell N., Geriatric Comedy: House Mother Normal [in:] N. Tredell Fighting Fictions: The Novels of B.S. Johnson, Nottingham 2010, p. 100-110. 